\title{
The Implication of Politeness and Speech Styles in Code Switching of Youth
} Javanese

\author{
Riris Sugianto ${ }^{1}$, L.Agung Rahmat Salehuddin ${ }^{2}$ \\ STMIK Mataram ${ }^{1,2}$ \\ sugiantoriris87@gmail.com
}

\begin{abstract}
ABSTRAK
Abstrak: Tujuan dari penelitian ini adalah untuk menampilkan penggunaan code-switching sebagai ekspresi dari kesopanan berbahasa dalam penggunaan bahasa Jawa. Artikel ini menekankan pada penggunaan di dalam lingkungan keluarga, dalam hal analisa percakapan. Artikel ini menampilkan bagaimana generasi muda tidak dapat menguasai gaya bahasa Jawa formal (basa) jadi mereka cenderung melakukan code-switching dari gaya bahasa Jawa formal (basa) ke penggunaan gaya bahasa Jawa yang tidak formal (ngoko) atau ke bahasa nasional kita yaitu bahasa Indonesia. Artikel ini menampilkan pengertian kesopanan dari beberapa teori dan menampilkan beberapa masalah yang berkaitan dengan konsep kesopanan dan gaya bahasa alam code-switching dalam keluarga Jawa khususnya untuk generasi muda. Lebih lanjut lagi, artikel ini memaparkan perbedaan penggunaan gaya bahasa baik untuk orang tua sebagai yang orang yang lebih tua dan anak-anak sebagai orang yang lebih muda di dalam keluarga. Ada bebereapa faktor yang mempengaruhi generasi muda melakukan codeswitching atau mengganti gaya bahasa mereka. Faktor itu meliputi partisipan, topik pembicaraan, tempat dan fungsinya. Satu kunci penting adalah setiap bahasa selalu memiliki karakteristik yang tetap, tetapi itu bisa menjadi dinamis khususnya ketika sebuah bahasa (Jawa) hadir berdampingan dengan bahasa lain (Indonesia). Secara teknis, dalam hal komunikasi, modifikasi dari peggunaan bahasa seperti codeswitching yang dibuat oleh pembicara akan terjadi dan tidak terhindarkan.
\end{abstract}

Kata Kunci: kesopanan, gaya bahasa, code switching, bahasa Jawa.

Abstract: The objective of this study is to present the use of code switching as expressions of politeness in Javanese language. This article is concern on the domain of family, in the terms of discourse analysis. This article present how the youth generation can not acquire the formal styles of Javanese (basa), therefore they tend to do code-switching from formal styles of Javanese (basa) to the use of informal styles of Javanese (ngoko) or to our national language, Indonesian. It provides definitions of politeness by theorists and presents some of the problems related to the concepts of politeness and speech styles in code-switching In Javanese families specifically for the youth generation. Furthermore, it looks into the differences usage of speech styles for both the parents as the elders and children as the youngers in the families. There are some factors of youth Javanese to switch their code. The factors are the participants, the topic, the setting and the function. One important key is every language always has stable characteristics, but it could be dynamic especially when the language (Javanese) exists side by side with another language (Indonesian). Technically, in the communication, the modification of language usage such as code switching that made by the speaker will be occur and unavoidable.

Key words: politeness, speech styles, code switching. 


\section{INTRODUCTION}

This research was inspired by the curiosity of the writer to find out about the use of code switching in terms of politeness and speech style in the conversations of the youthof Javanese. As we know, in this modern era, traditional languages such as Javanese are rarely used even though in Javanese families themselves, especially for young people, they tend to use Indonesian in everyday conversation. This is because the Javanese have characteristics that are more complex and have various types of speech that must be used based on the status of the interlocutor. In this study, the writer will present politeness and speech style in Javanese family conversations. This phenomenon in the youth generation is widespread because they often change their language (Javanese) when they talk to their parents or siblings when they want to say something politely. This phenomenon related to politeness theory related to this study, Lakoff (1990 in Mahyuni 2006: 30) defines politeness as "a system of interpersonal relations designed to facilitate interaction by minimizing the potential for conflict and confrontation inherent in all human exchanges". Lakoff pointed out the importance of maintaining a harmonious relationship between participants both the speaker and the recipient or the interlocutor during interaction. Furthermore, in Indonesia, the term politeness depends on the language of speech style. In this study the emphasis is on the use of Javanese, the Javanese language that has historically been associated with the area is characterized by a series of speech styles or complex levels of language used to express and index the nature of the relationship between the speaker and the interlocutor.

In Javanese, there is no interaction that is linguistically neutral. During each conversation the speaker must assess their relative social position and choose the appropriate style of speech with the recipient. Even in the family conversations, children are expected to talk to their parents in a more respectful manner and will receive a more familiar response in return. In this case, Javanese parents have an important role to play in making their children obtain their mother tongue like Javanese, there may be families where parents as decision makers apply regulations including the use of language for their children at home. Like Holmes et al. (1993) argue that there is a relationship between parent-child and language at home. They stated that one of the most important factors contributing to the preservation of minority languages was the use of ethnic languages in the home environment. This means parents play an important role in conveying their ethnic language to their children. While all parents from one language community take a stand to teach their child's language skills, multilingual parents should be more routine if they want their children to learn their mother tongue. If not, children will only get the majority language. Tuominen (1999) found that children in a bilingual or multilingual family had the potential to have significant power over the language used at home. It seems that children usually determine the language of the house in the family, even when 'language rules', which are like mother tongue, are applied by their parents.

However, there may be families that give their children the freedom to choose their language, or maybe there are families who do not care what language their parents choose, children still use the language they like. Therefore, it often happens when their parents speak Javanese to their children, sometimes children will switch to languages they like and are familiar with like Indonesian. 
With regard to this phenomenon, there is another theory of language transfer that underlies this study. When people use more than one language, the language is called language transfer or code transfer in sociolinguistics (Hymes in Chaer and Agustina, 2004: 107). Code transfer occurs in bilingual and multilingual communities when one switches from one language, variation, or dialect to another. People can do code switching in any situation and domain. The social context affects someone to convey information by changing different communication codes. There are many cases of code transfer that occur in families, schools, offices, and communities. In families, code switching occurs when family members switch from one language to another in their communication. Therefore, this study will analyze the use of code-switching in terms of politeness and speech that occur in the daily conversations of Javanese youth in their families.

This research analyzes two problems; What are the implications of politeness and speech style in code-switching of Javanese family? And what factors influence Javanese youth to use code switching in their daily conversations with their family members? This paper also offers a solution for youth Javanese, to find out some of the factors that influence code-switching use in their families? and to find out some factors that influence Javanese youth to use code-switching in their daily conversations with their family members.

This study discusses how Javanese youth maintain their language to be polite by making code switching in their interactions with their parents. The study also aims to offer solutions to the above problems, so that the youth Javanese can be polite when they are involved in communication with their parents in their native language.

\section{RESEARCH METHODS}

In the Indonesian context, modesty depends on the level of speech and linguistic ethics. In Indonesia, Javanese is the language whose language style is most studied. According to Grize (in Mahyuni 2006: 34) he emphasized the importance of the style of speech in the Javanese language system because it carries what he calls "status meaning", this refers to the way Javanese words are used in real conversations, such as lexical choices. Don't refer only to literal meaning, but also convey connotative meanings about the status of the speaker and recipient.

According to Poedjosoedarmo (1968 in Mahyuni 2006: 96) he argues that Javanese has a complex speech level system based on four types of vocabulary, and two types of affixes, where each level has three sublevels. In general, this level is included in: ngoko, madya, and krama:

\section{Ngoko (informal)}

This is used between friends and close relatives. It is also used by people who have higher status when talking to people of lower status, such as parents who talk to young people or parents who handle children.

\section{Madya (informal polite, netral)}

This is an intermedial list that is neither formal nor formal. This is used in informal situations such as between strangers on the streets.

\section{Krama (formal polite)}

This is used between individuals with equal status in formal situations. It is also used in official announcements and public speeches.

The three Javanese language styles can be simplified into two categories; Ngoko and Basa, Basa is a general term for what can actually be further divided into: madya and 
karma. The use of different styles is complicated and requires thorough knowledge of Javanese culture. Most Javanese do not acquire all styles. They usually learn Ngoko. Javanese youth have problems with learning the stratification of this language.

From a cultural perspective, speakers of Javanese must consider two important aspects: first, the listener, the speaker must consider factors such as social status, age, gender, education level, descent and social strata of the interlocutors. Second, how users express language, this requires the speaker to consider the socio-cultural elements of Javanese culture such as speaking politely and respectfully. Failure to develop aspects of this interaction can result in unharmonious conversations and the speaker will be considered durung Jowo 'not yet a Javanese' or due to 'lack of understanding manners'. In Javanese society, this term has a 'negative' connotation, indicating that the speaker has not been able to control his emotions, and as a result, can interfere with interaction.

Associated with the level of politeness, the other person tends to do code-switching or to be polite. The transfer of language as part of the topic in this study is part of a sociolinguistic study related to the relationship between language and the context of its use (Holmes, 2001: 1). Sociolinguistics actually focuses on how language is used, so the role of sociolinguistics is to manage language as it functions in society. In this term, sociolinguistics is part of the conversation. As Wardhaugh (1992: 95) states that language transfer is often done accidentally. People may not realize that they do codeswitching or language transfer. As a result, when speakers from various languages communicate with each other fluently, they often use words and sentences using different languages in one conversation, and switch from one language to another. Such conversational strategies that are intentionally and unintentionally are known in linguistics as code-switching. In language transfer, the speaker speaks in two languages but both languages are in one sentence and in one sentence there will be several words in another language.

The method used in this study is the interview method in a family environment that emphasizes the use of code-switching in the home environment. Interviews in a family that has parents from Java and Sasak. For this study the use of Javanese is more emphasized. Interviews started with parents; Father (Javanese) and Mother (Sasak) where parents are elder people so that in ways of speaking with younger family members it will be different, children and other family members.

\section{DISCUSSION}

Facing the problem revealed in this study: what are the implications of politeness and speech style in code switching of Javanese youth in their everyday conversations with their family members? And what factors influence Javanese youth to use code switching in their daily conversations with their family members?

Javanese youth have problems with studying the stratification of Javanese speaking styles. Recent research on Javanese language skills towards students found that Javanese children were unable to apply correct manners of vocabulary in formal dialogue. (Wibawa and Nafalski, 2010: 216). This is caused by the community, Javanese youth tend to use Indonesian in their daily conversations. Although sometimes if they talk to their family members, they still use polite words when talking to their parents, but sometimes that doesn't happen right, because sometimes they don't master polite Javanese style (krama). That makes Javanese youth have to use code-switching. 
Furthermore, there is a stereotype that Javanese is only for parents, some Javanese youth feel more comfortable using Indonesian and consider it more communicative and uncomplicated. On the contrary, in Javanese we must really distinguish our language depending on the people we face if they are older or younger. There are several examples of using codeswitching in terms of politeness in JavaneseIndonesian:

- Pak dhahar dulu yok, Pak

(Pak, let's eat first)

- Mas lagi siram, bu

(Mas is taking a shower, bu)

- Bapak mau tindak kantor sekarang ta?

(Do you want to go to the office now, Pak?)

- $\quad$ Aku sek salin baju, ki lo bu

(I am changing my clothes, bu)

- Mbak, bade nyuwun pulsa yo, aku gak ada pulsa buat sms

(Mbak, I want to ask for the balance, I don't have any balance for texting)

Based on the example above, it can be concluded that the implications of politeness and speech style in code switching in Javanese families occur when Javanese youth are aware of switching their language and it is in accordance with the interlocutor and situation, if the recipient or interlocutor has a high status like grandfather, grandmother, parent, sister or brother, then code switching will occur. In some cases, transition occurs because of a change in situation that is influenced by a function factor in which the speaker switchs the language from Javanese to Indonesian with a specific purpose for the recipient. Therefore, it can be said that this is more polite compared to Indonesia.
Furthermore, the second problem in this paper is what factors influence Javanese youth to use code switching in their daily conversations with their family members? In the process of code-switching, there must be factors that influence the occurrence of code switching. The factors that influence code switching can be categorized in listeners, topics, functions, and settings based on Holmes (2001: 12).

\section{CONCLUSION}

In most Javanese families, with children who use more polite style of speech to older people, their parents and receive a more familiar response in return. Sometimes they tend to switchs their language so that their speech sounds polite, the cause of code-switching is largely because the speaker speaks in one language in one situation and then switches to another language in the situation and other participants. The authors find that there are several factors for Javanese youth who do codeswitching. The factors are listeners, topics, place settings and functions. Some suggestions that the writer might give in this study are Javanese youth can switch their language if they talk to older people to say polite words. In this term, Javanese youth also maintain their mother tongue in the global region as it is today.

\section{REFERENCES}

Chaer, Abdul and Agustina, Leoni. 2004. Sosiolinguistik: Perkenalan Awal. Jakarta: Rineka Cipta.

Holmes, Janet. 2001. "An Introduction to Sociolinguistics (2nd edition)", New York : Longman.

Mahyuni. 2006. "Speech Styles and Cultural Consciousness in Sasak Community", Mataram: Cerdas Press.

Wibawa and Nafalski. 2010. "Intelligent tutoring system: a proposed approach to Javanese language learning in Indonesia". World Transactions on Engineering and Technology Education, Vol.8 No.2. 